\title{
Comportamiento físico del mármol blanco de Macael (España) por oscilación térmica de bajo y medio rango
}

\author{
Performance of Spanish white Macael marble exposed \\ to narrow- and medium-range temperature cycling
}

\author{
J. Rodríguez Gordillo(*), Ma P. Sáez Pérez ${ }^{(*)}$
}

Recepción/Received: 5-X-07

Aceptación/Accepted: $12-\mathrm{V}-08$

Publicado online/Online publishing: 15-II-10

\section{RESUMEN}

Se aplican ciclos de estrés térmico de medio (100/-20 ㄷ y $75 /-20^{\circ} \mathrm{C}$ ) y bajo $\left(50 /-20^{\circ} \mathrm{C}\right)$ rango sobre probetas de mármol blanco de Macael (Almería, España), y se evalúa ciclo a ciclo su incidencia mediante ultrasonidos. Los resultados indican un considerable descenso de velocidad de los ultrasonidos en las muestras sometidas a estrés de $100 /-20^{\circ} \mathrm{C}$, más moderado en el caso de $75 /-20^{\circ} \mathrm{C}$, poco significativo en el caso de $50 /-20^{\circ} \mathrm{C}$. Las variaciones de velocidad tienen lugar durante los primeros 5-7 ciclos, permaneciendo los valores constantes en ciclos posteriores. Los resultados proporcionados por medidas de dureza de Schmidt, y de rotura por compresión uniaxial son coincidentes con los proporcionados por los ultrasonidos. Las imágenes de microscopía petrográfica y electrónica (SEM) manifiestan una cierta descohesión granular en zonas muy superficiales de las probetas sometidas a 40 ciclos de $100 /-20^{\circ} \mathrm{C}$. La coincidencia entre los datos por las técnicas de rotura por compresión, medidas de dureza superficial y ultrasonidos indican la validez de estas dos últimas -técnicas no destructivas, NDT- en el control de la incidencia de ciclos de stress térmico sobre las características mecánicas de materiales pétreos.

Palabras clave: mármol blanco Macael, deterioro termal, durabilidad, técnicas no destructivas, petrofísica.

\section{SUMMARY}

White marble specimens from Macael in the Spanish province of Almeria were exposed to narrow- (50/ $\left.-20{ }^{\circ} \mathrm{C}\right)$ and medium- $\left(100 /-20^{\circ} \mathrm{C}\right.$ and $\left.75 /-20^{\circ} \mathrm{C}\right)$ range thermal stress cycles. The effects were monitored with ultrasound techniques. Ultrasound velocity declined considerably in samples subjected to $100 /-20^{\circ} \mathrm{C}$ cycles, more moderately when the range was $75 /-20^{\circ} \mathrm{C}$ and insignificantly when it was narrowed to $50 /-20{ }^{\circ} \mathrm{C}$. All variations were recorded in the first five to seven cycles, with values flattening thereafter. The Schmidt hardness and compression test results concurred with the ultrasound findings. Petrographic and scanning electron microscope (SEM) imaging revealed some very superficial granular decohesion in the specimens subjected to forty $100 /-20^{\circ} \mathrm{C}$ cycles. The concurrent results from compression testing on the one hand and surface hardness and ultrasound measurements on the other confirmed the validity of the latter two nondestructive techniques (NDT) for determining the effects of thermal stress cycling on stone mechanical strength.

Keywords: white Macael marble, thermal decay, durability, non-destructive techniques, petrophysics.

(*) Universidad de Granada (Granada, España). 


\section{INTRODUCCIÓN}

Desde los trabajos de (1) en los que se introdujeron estudios experimentales de calentamiento/enfriamiento de rocas, numerosos estudios han establecido de manera fehaciente la relación entre las oscilaciones térmicas a que se ven sometidos los materiales pétreos en monumentos y edificaciones, y gran parte de las diversas formas de degradación o deterioro que presentan. Aspectos como composición mineralógica y características cristalográficas y microtexturales marcarán la respuesta del material pétreo a las condiciones ambientales a las que se encuentre expuesto, y entre ellas, a los cambios más o menos rápidos e intensos de temperatura. Citamos como ejemplo, por lo reciente y por sus aportaciones, los trabajos de (2-16) entre otros.

En materiales marmóreos son estos cambios continuados de temperatura más o menos acelerados los responsables de alteraciones como es la desagregación de material en superficie (disgregación, desplacados, microfisuraciones...). Es el caso de las columnas de mármol ("mármol blanco Macael") del Patio de los Leones de la Alhambra de Granada. Por todos es conocida que la famosa fuente, sus leones y las columnas que soportan las galerías y los pabellones del Patio tienen importantes problemas de conservación. Concretamente, las columnas están afectadas por pérdida de material, manchas, etc., las cuales en algunos casos tienen un impacto en su estética, aunque no en su capacidad estructural (17) y (18). La importancia histórico-artística de este Monumento ha propiciado el interés por conocer las causas y posibles soluciones a su proceso de degradación, fundamentalmente en forma de microfisuraciones y pérdidas de material por microdesplacados. Diversos trabajos han puesto de manifiesto la relación directa entre el grado de insolación a que se ve expuesto el material y su tipo y grado de deterioro, se citan como ejemplos (17-23).

Recientes estudios experimentales sobre material marmóreo de igual procedencia y características que el de estas columnas (mármol procedente de Macael, España), han revelado la enorme incidencia que ciclos repetidos de calentamiento/enfriamiento tienen sobre las características físico-mecánicas de este material. En los trabajos de (18) y (19), se comprobó que tras someter el material a 50 ciclos de calentamiento-enfriamiento (entre $100^{\circ} \mathrm{C}$ y $-20^{\circ} \mathrm{C}$ ), éste experimentaba una disminución del orden del $20 \%$ de su resistencia mecánica, y una disminución de la velocidad de transmisión de pulsos ultrasónicos del 40-50\%. Dichas experiencias demostraban igualmente que ciclos posteriores de calentamiento/enfriamiento no tenían apenas incidencia sobre las citadas características del material. Esta disminución tan acusada de las características mecánicas del mármol blanco de Macael tras 50 ciclos entre $100{ }^{\circ} \mathrm{C}$ y $-20^{\circ} \mathrm{C}$ nos ha hecho considerar la

\section{INTRODUCTION}

Ever since the earliest experiments (1) were conducted to analyze rock performance under heating and cooling cycles, any number of studies (2-16) have confirmed the relationship between the exposure of stonework to wide fluctuations in temperature and its decay or deterioration. Mineralogical composition, crystallography and microtexture affect a stone's response to environmental conditions, including relatively steep temperature changes.

In marble, these continuous, more or less abrupt temperature changes induce alterations such as loss of surface matter (flaking, scaling, microcracks and so on). The white Macael marble columns in the Courtyard of the Lions, one of the highlights of the Alhambra Palace in Granada, have undergone such weathering. The famous fountain with its lions and the columns supporting the courtyard's galleries and pavilions are known to constitute a substantial conservationist challenge. More specifically, the columns exhibit material loss, staining and so on, which in some cases affect their appearance but not their bearing capacity (17) and (18). In light of the monument's historic and artistic value, much effort has been invested in understanding the causes of and possible solutions to its decay, primarily in the form of microcracks and micro-scaling and the concomitant loss of material. A number of studies (17-23) have drawn a direct relationship between the degree of insolation to which stone is subjected and the type and degree of decay.

Recent experimental research on marble of the same origin (Macael, Spain) and characteristics as the material in these columns has shown that serial heating/cooling cycles impact the stone's physicalmechanical properties substantially. Two such studies (18) and (19) found that after 50 heating-cooling cycles (between $100^{\circ} \mathrm{C}$ and $-20^{\circ} \mathrm{C}$ ), the stone's mechanical strength declined by around $20 \%$ and ultrasound transmission velocity by $40-50 \%$. These experiments also showed that further heating-cooling cycles had little effect on these parameters. The very steep decline in the mechanical strength of white Macael marble suggested the need for further experimental study with fewer cycles and narrower ranges of thermal fluctuation to better understand the behaviour at ambient temperatures of this stone, whose remarkable quality and beauty explain its 
necesidad de nuevos estudios experimentales sobre el efecto de un menor número de ciclos, y de rangos de variación térmica inferiores, lo que nos permitirá un mejor conocimiento del comportamiento térmico-ambiental del mármol blanco de Macael, material de uso y presencia muy extendido en el patrimonio artístico-monumental español dada su calidad y belleza, lo que justifica el estudio específico de su comportamiento.

En el presente trabajo se estudia por tanto la evolución de este material marmóreo ciclo a ciclo, tanto en los intervalos de temperatura citados $\left(100^{\circ} \mathrm{C}\right.$ a $\left.-20^{\circ} \mathrm{C}\right)$, como a otros intervalos de temperatura inferiores, lo que supone por otra parte una mayor aproximación a las condiciones y gradientes térmicos reales a las que el material se encuentra expuesto en el monumento. Los estudios mediante medidas de velocidad de propagación de ultrasonidos, técnica esencial por su carácter no destructivo, nos ha permitido seguir la evolución del material ciclo a ciclo. El control de la evolución del material se ha completado mediante ensayos de resistencia mecánica, y estudios de microscopía óptico-petrográfica y electrónica.

\section{MATERIALES Y MÉTODOS}

El material empleado en el estudio ha sido el denominado "mármol blanco Macael" (Almería, España), igual al empleado en estudios precedentes (19), y específicamente el más blanco o con menor proporción de bandeados grises.

Los mármoles de Macael pertenecen al Complejo Nevado-Filábride en la llamada Zona Bética Interna (24). En este complejo se desarrollan diferentes unidades que han sufrido en general procesos de metamorfismo de bajo gradiente térmico y alta presión, seguido por otros de gradientes térmicos más altos. Tanto el metamorfismo como las deformaciones posteriores que han experimentado son de edad alpina. El material característico de esta formación son las rocas carbonatadas de edad Triásico superior, aunque a veces aparecen alternancias de estas rocas carbonatadas con micasquistos, micasquistos calcáreos, micasquistos cuarcíticos con granate y micasquistos cuarcíticos con anfíbol.

El material utilizado es un mármol de tipo granoblástico, variando desde equigranular, con grano de gran tamaño, hasta grano medio-fino heterogranular. Contiene además pequeñas cantidades de cuarzo y cristales aislados de moscovita y feldespato. En las zonas donde el bandeado gris se hace visible se observan cristales de epidota, titanita y pirita.

Las probetas ( $5 \times 5 \times 15 \mathrm{~cm}$ ) se han cortado ajustando la dirección de los bandeados grisáceos del material a la extensive use in Spain's artistic and monumental heritage.

This paper focuses on the cycle-by-cycle variations in the marble at both the 100 to $-20^{\circ} \mathrm{C}$ range and narrower temperature fluctuations in an attempt to simulate the actual gradients to which the stonework on the monument in question is exposed. Cycle-by-cycle monitoring was conducted by measuring ultrasound velocity, a non-destructive technique. Variations in stone properties were likewise identified with mechanical strength tests as well as optical petrographic and scanning electron microscopy.

\section{MATERIALS AND METHODS}

The stone used in this as well as previous studies (19) was white Macael marble (Almeria, Spain), and more specifically the whitest variety with the least intense grey banding.

Macael marble forms part of the Nevado-Filabride Complex in the Baetic Internal Zones (24). During their formation, a number of units in this complex first underwent low thermal gradient, high pressure metamorphic processes, followed by processes with a higher thermal gradient. The metamorphism and subsequent deformations all took place in the Alpine Age. Late Triassic carbonate rocks are typical of this formation, although they occasionally alternate with micaschists, calcareous micaschists, quartzite micaschists with garnate and quartzite micaschists with amphibole.

The granoblastic marble used for this study ranged from equi-granular, large grain to heterogranular medium-fine grain stone. It also contained small amounts of quartz and isolated muscovite and feldspar crystals. Epidote, titanite and pyrite crystals were identified in the grey bands.

Specimens measuring $5 \times 5 \times 15 \mathrm{~cm}$ were cut so that the greyish bands ran along their length, parallel to one of 
máxima dimensión de las mismas y paralelos a una de las caras laterales. Hemos optado por denominar $\mathrm{Z}$ a la dirección según el eje longitudinal (altura de la probeta), $X$ a la dirección perpendicular a $\mathrm{Z}$ y paralela a los bandeados grisáceos (profundidad), e $Y$ a la dirección perpendicular a los mismos (anchura), Figura 1. the side faces. The longitudinal direction (specimen height) was defined to be the $Z$ axis, the direction perpendicular to $Z$ and parallel to the grey bands (depth) the $X$ axis and the direction perpendicular to these bands (width) the $Y$ axis (Figure 1).

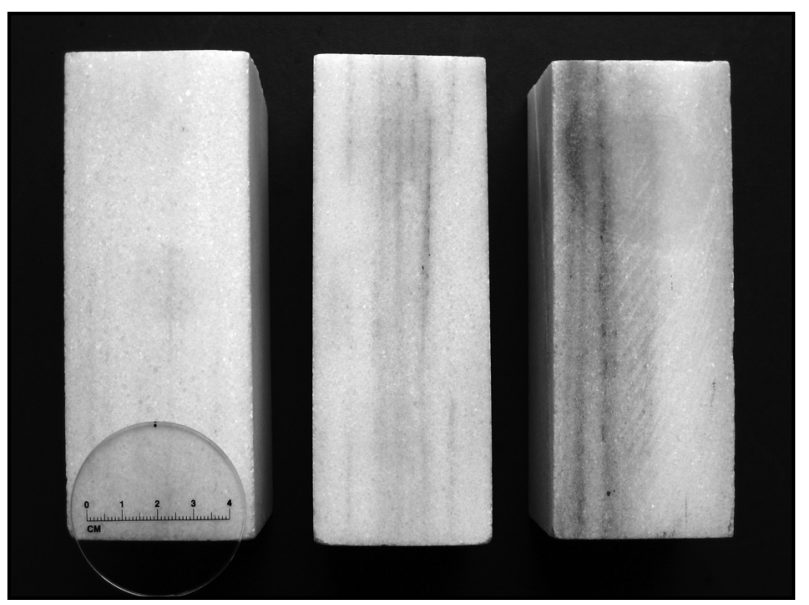

Figura 1. Imagen de algunas de las probetas sometidas a ensayo con intensidad creciente de bandeado grisáceo. Figure 1. Test specimens with increasing intensity of grey banding.

\subsection{Ciclos térmicos (calentamiento/enfriamiento)}

Ciclos diarios de calentamiento/enfriamiento entre $100^{\circ} \mathrm{C}$ y $-20^{\circ} \mathrm{C}\left(6\right.$ horas a $100{ }^{\circ} \mathrm{C}, 6$ horas a temperatura ambiente, 6 horas a $-20^{\circ} \mathrm{C}$ y 6 horas a temperatura ambiente). Tras cada ciclo de calentamiento/enfriamiento se ha medido la velocidad de propagación de ultrasonidos una vez las probetas han alcanzado la temperatura ambiente. El número de probetas ensayadas ha sido de 10, y el número de ciclos 40 .

Ciclos de enfriamiento exclusivamente (12 horas a $-20^{\circ} \mathrm{C}$ y 12 horas a temperatura ambiente), midiéndose la velocidad de propagación de ultrasonidos en cada ciclo, una vez las probetas han alcanzado la temperatura ambiente. El número de probetas ensayadas ha sido de 10 , y el número de ciclos 10 .

Ciclos y medidas de ultrasonidos como los descritos anteriormente, manteniendo intervalos de temperatura de $75^{\circ} \mathrm{C}$ a $-20^{\circ} \mathrm{C}$ en un caso, e intervalos de $50{ }^{\circ} \mathrm{C}$ a $-20^{\circ} \mathrm{C}$ en otro. El número de probetas ensayadas ha sido de 10, y 10 el número de ciclos en ambos casos.

Mantenimiento de 10 probetas durante 30 días a $-20^{\circ} \mathrm{C}$. Se midió la velocidad de ultrasonidos antes del enfriamiento, y tras los 30 días de enfriamiento tras mantener 6 horas las probetas a temperatura ambiente. Transcurridos tres días a temperatura ambiente tras el mes de enfriamiento se volvió a medir la velocidad de ultrasonidos en las probetas.

\subsection{Thermal cycles (heating/cooling)}

The specimens were exposed to heating and cooling cycles on a daily basis: the protocol called for heating at $100^{\circ} \mathrm{C}$ for 6 hours, cooling to laboratory temperature for 6 hours, chilling to $-20^{\circ} \mathrm{C}$ for 6 hours and finally warming to laboratory temperature for 6 hours. Ultrasound velocity (UV) was measured when the specimens had reached laboratory temperature after heating or cooling. Ten specimens were subjected to 40 cycles each.

A further 10 specimens were cooled only (12 hours at $-20{ }^{\circ} \mathrm{C}$ and 12 at laboratory temperature). Here also ultrasound velocity was measured at ambient temperature.

Two other series of 10 specimens each were exposed to hot/cold cycling, the ranges being 75 to $-20^{\circ} \mathrm{C}$ and 50 to $-20^{\circ} \mathrm{C}$. UV readings were taken as above.

Lastly, 10 specimens were stored at $-20^{\circ} \mathrm{C}$ for 30 days. In this case, ultrasound velocity was measured before cooling and after the 30-day period, when the specimens were allowed to warm to laboratory temperature for 6 hours. These measurements were repeated after three days at room temperature. 
Los ciclos de calentamiento/enfriamiento se han realizado manteniendo las probetas en horno de calentamiento por convección y frigorífico respectivamente. Las condiciones ambientales de medida han sido $25^{\circ} \mathrm{C}$ y $55 \% \mathrm{HR}$.

En ningún momento las probetas estuvieron en contacto con el agua líquida.

El calentamiento del material en un monumento y ambiente soleado tiene lugar fundamentalmente por radiación. En el estudio de (25) se establecen diferencias entre las temperaturas superficiales que pueden alcanzar distintos tipos de materiales pétreos según su régimen de calentamiento sea por convección o radiación (mayor siempre en este caso), así como su evolución hacia el interior del material. En este estudio se pone de manifiesto que estas diferencias en la evolución de la temperatura de la superficie al interior del material según el régimen de calentamiento, es muy dependiente del color y capacidad de absorción lumínica (albedo o reflectancia relativa superficial) del material (26) y (27). Dado el alto albedo y blancura del mármol de Macael empleado en nuestras experiencias, las diferencias que podrían resultar según un régimen de calentamiento u otro son irrelevantes, por lo que dada la mayor simplicidad de equipamiento requerida, se ha optado por mantener en nuestro trabajo el calentamiento por convección, lo que nos permite, por otra parte, una mejor correlación con los datos obtenidos en anteriores experiencias.

\subsection{Ultrasonidos}

Las medidas de velocidad de propagación de ultrasonidos en cada probeta se han hecho según las direcciones $Z$ (altura), X (profundidad) e Y (anchura). El método utilizado ha sido el método de transmisión directa de impulsos ultrasónicos, VP. Se han seguido las recomendaciones propuestas por (28-29). El equipo de ultrasonidos empleado es el modelo Steinkamp BP V con generador de impulsos de baja potencia, con capacidad para generar impulsos de 50 y $100 \mathrm{KHz}$. Dadas las dimensiones de las probetas se ha trabajado con ondas de $100 \mathrm{KHz}$. El diámetro de apoyo de los transductores sobre las probetas fue de $3 \mathrm{~cm}$. El material de interfase transductor-piedra han sido las piezas de material siliconado proporcionadas con el equipo.

A partir de los valores de velocidad de propagación en las tres direcciones indicadas se ha establecido el coeficiente de anisotropía del material marmóreo. Se ha obtenido el "Índice de Anisotropía Estructural Total $\Delta \mathrm{M}(\%)$, y el Coeficiente de Anisotropía Relativa $\Delta \mathrm{m}(\%)$, a partir de las relaciones matemáticas entre las velocidades de propagación de los ultrasonidos (30-31).
Specimens were heated in a convection oven and cooled in a freezer. The ambient conditions for measurement were $25^{\circ} \mathrm{C}$ and $55 \% \mathrm{RH}$.

The specimens were not in contact with liquid water at any time.

In insolated monuments, stonework is heated primarily by radiation. One study (25) reported the difference in surface temperatures recorded for stone materials depending on whether they were convection- or radiation-heated (always higher in the latter), as well as the temperature gradient from the surface inward. The present findings showed that surface and inner temperature differences attributable to heating procedure depend heavily on stone colour and capacity to absorb light (reciprocal to albedo or the fraction of incident light reflected back in all directions) (26) and (27). The very high albedo of the white Macael marble used in the present experiments rendered the differences between heating procedures irrelevant. Consequently, convection heating was deployed, in light of the less sophisticated equipment required and for reasons of comparability with data gathered in previous experiments.

\subsection{Ultrasound}

Ultrasound velocity was measured in each specimen in the three directions: $Z$ (height), $X$ (depth) and $Y$ (width). Ultrasonic pulse velocity (UPV) was determined by direct transmision testing, pursuant to spanish and italian standards (28-29). A Steinkamp BP V ultrasonic tester fitted with a low power, 50- and 100-kHz pulse generator was used. The $100-\mathrm{kHz}$ option was chosen, for it was found to be better suited to the specimen size. The diameter of the transducer in contact with the specimen was three $\mathrm{cm}$. The silicone material supplied with the tester was placed at the transducer-stone interface.

The anisotropy index for the marble was determined from the UPV values read in the three test directions. The total structural anisotropy factor, $\Delta M(\%)$, and relative anisotropy factor, $\Delta m(\%)$, were obtained from the mathematical relationships between ultrasound pulse velocities (30-31). 


\subsection{Microscopía óptico-petrográfica y microscopía electrónica de barrido (SEM)}

Mediante microscopía petrográfica de luz polarizada y microscopía electrónica de barrido (SEM) se ha abordado el estudio de la probable incidencia de los ciclos de estrés térmico en el grado de agregación inter e intragranulares del material marmóreo.

El equipo usado para la microscopía petrográfica ha sido un microscopio óptico de polarización con luz transmitida y reflejada Zeiss modelo Jenalab Pol. El estudio de microscopía electrónica (visualización y toma de fotografias) se ha efectuado con un equipo Zeiss DSM 950 equipado con un microanalizador Link QK 2000. Previamente, láminas y probetas fueron observadas con un microscopio binocular Wild M8 con fuente iluminante de "luz fría".

\subsection{Resistencia mecánica}

Se han realizado determinaciones de esfuerzo-deformación y carga de rotura para probetas sometidas y no sometidas a los ciclos de estrés térmico La metodología empleada para la realización de este ensayo en nuestro caso se ha regido según (32). El número de muestras ensayadas ha sido de 50, distribuidas en tandas de 10 probetas para cada uno de los grupos sometidas a los distintos ciclos de estrés térmico.

Para la medición de la deformación se han empleado dos bandas extensiométricas (TML PFL 10-11) colocadas paralelamente al eje en lados opuestos de la probeta, obteniéndose el promedio de ambas deformaciones. La prensa utilizada en este ensayo ha sido una Ibertest MEH $2000 \mathrm{CO}$, posee unas características de carga regulables que oscilan desde $2 \mathrm{kN}$ hasta $2.000 \mathrm{kN}$, ofreciendo un registro continuo de dos parámetros: esfuerzo $(\mathrm{MPa})$ y deformación $(\mathrm{mm} / \mathrm{m})$, hasta la rotura de la probeta. La velocidad de carga aplicada ha sido de $\approx 0,7 \mathrm{MPa} / \mathrm{s}$.

\subsection{Medidas de dureza de Schmidt (esclerómetro)}

El ensayo de resistencia mecánica descrito anteriormente es el que permite evaluar de manera directa la evolución de las características mecánicas del material. No obstante, y dado su carácter totalmente destructivo, hemos considerado introducir -además de los ultrasonidos y a título de comprobación- otra técnica no destructiva (TND).

Se ha optado por el uso del esclerómetro o "rock clasification hammer". Se trata de un ensayo no destructivo por el que se obtiene el índice de rebote también llamado índice de rechazo o dureza de Schmidt. A partir de

\subsection{Optical-petrographic microscopy and scanning electron microscopy (SEM)}

Polarized light petrographic microscopy and scanning electron microscopy were used to study the probable effects of thermal stress cycles on inter- and intragranular cohesion in the marble.

Petrographic exploration was conducted with a Zeiss Jenalab Pol transmitted and reflected light optical microscope. A Zeiss DSM 950 SEM fitted with a Link QK 2000 microanalyzer was used for scanning electron visualization and photography. Sections and specimens were examined in a preliminary phase under a Wild M8 stereo microscope with a cold light source.

\subsection{Mechanical strength}

Stress-strain and failure load measurements were taken for both the control and treated specimens, pursuant to the specifications in Spanish standard UNE 22-187-85 (32). A total of 50 specimens were tested, 10 per test regimen.

Strain was measured with two TNL PFL 10-11 strain gauges positioned on opposite sides of the specimen, along the axis. The value used was the mean of the two readings. A 2- to 2000-kN Ibertest MEH 2000 CO testing machine was used for compression testing. Both stress (MPa) and strain $(\mathrm{mm} / \mathrm{m})$ were recorded continuously through specimen failure. The loading rate was $\approx 0.7 \mathrm{MPa} / \mathrm{s}$.

\subsection{Schmidt hardness measurements (impact hammer)}

While the mechanical strength test described above provided for direct assessment of stone strength, in light of its destructive nature, a need was felt for a second non-destructive technique (NDT), in addition to UPV.

The method chosen was impact rebound and the instrument the rock classification hammer, whose rebound readings were used to find the Schmidt hardness index. These readings, plotted against stone 
estos datos y de la densidad del material, las oportunas gráficas (33) proporcionan los valores de resistencia a compresión y módulo de elasticidad del material.

Se han realizado las medidas de dureza de Schmidt de todas las probetas sometidas a los diferentes ciclos de calentamiento/enfriamiento, así como sobre 10 probetas no sometidas a dichos ciclos. En cada probeta las medidas se han efectuado en las tres direcciones predeterminadas del prisma $(Z, X$ e $Y)$. Además, a partir de los datos índice de rebote y como se indica anteriormente, se han obtenido los valores de resistencia a compresión y módulo de elasticidad.

El equipo utilizado ha sido un esclerómetro o martillo clasificador de rocas blandas modelo 45-D056 de la casa CONTROLS SrL. (33).

\section{RESULTADOS Y DISCUSIÓN}

En la Figura 2 se recogen imágenes de muestras tras los diferentes ciclos de calentamiento/enfriamiento; no se observan variaciones de composición mineralógica, y en cuanto a efectos de los tratamientos térmicos sobre disposición granular, posibles fracturas, separaciones intergranulares, etc., sólo en la muestra sometida a 40 ciclos entre -20 y $100{ }^{\circ} \mathrm{C}$ parece observarse en algunas zonas próximas al borde superficial un mayor resalte u obscurecimiento de las líneas de separación granular, lo que podría interpretarse - con muchísima cautela - como un aumento de la separación granular por efecto de una mayor oscilación térmica, su escasísima entidad no permite su cuantificación. La imagen indica que este efecto se extiende - con un reparto desigual- unos 2-2,5 mm de profundidad. density (33), give stone compressive strength and modulus of elasticity.

Schmidt hardness measurements were taken on all the specimens subjected to the thermal stress cycling, as well as on 10 untreated or control specimens. Readings were taken in directions $X, Y$ and $Z$ and used, as noted above, to determine compressive strength and modulus of elasticity.

A CONTROL SrL 45-D056 Schmidt hammer for soft rock was used (33).

\section{RESULTS AND DISCUSSION}

Photographs of specimens after thermal cycling are shown in Figure 2. No mineralogical alterations were observed. The possible effects of temperature cycling on granular cohesion - fracturing, intergranular separation and so on - were detected only on the specimen exposed to forty 100 to $-20^{\circ} \mathrm{C}$ cycles, where the grain contours to be enhanced or somewhat darker. While this might, with all due caution, be interpreted to be attributable to widened separation as a result of steeper thermal fluctuations, the effect is too small to quantify. The photograph shows that the effect extends unevenly to a depth of approximately 2-2.5 $\mathrm{mm}$.

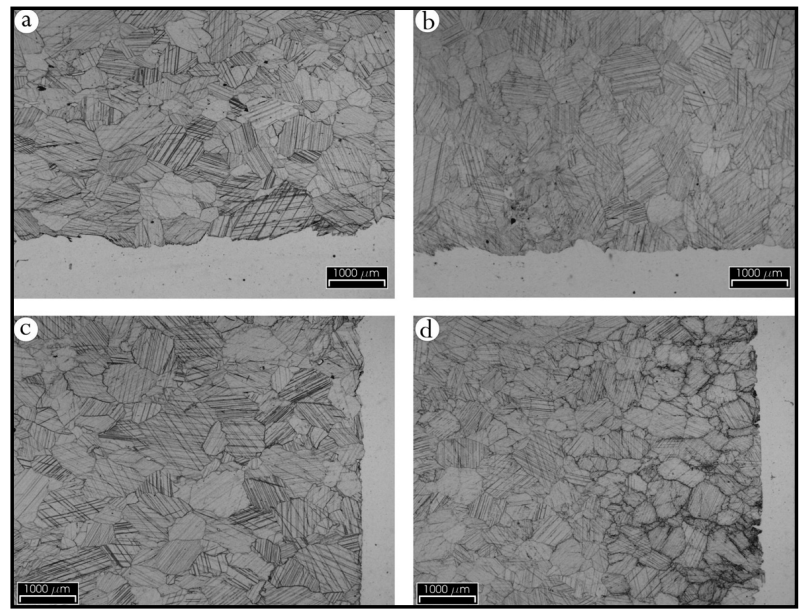

Figura 2. Imagen de microscopía óptico-petrográfica de muestras no tratadas (a), y tras ciclos de $50 /-20{ }^{\circ} \mathrm{C}$ (b), $75 /-20{ }^{\circ} \mathrm{C}$ (c) y $100 /-20^{\circ} \mathrm{C}$.(d) Nótese la mayor definición de bordes de grano en la zona externa de la muestra d.

Figure 2. Optical micrograph of: (a) control specimens; specimens after cycling at (b) 50/-20 ${ }^{\circ} \mathrm{C}$; (c) $75 /-20^{\circ} \mathrm{C}$; and (d) $100 /-20{ }^{\circ} \mathrm{C}$. Note the darkened grain contours on the area closest to the surface in specimen $d$. 
Por lo que respecta a la incidencia de los diferentes tratamientos térmicos sobre la velocidad de propagación de los ultrasonidos a través de las probetas, en la Figura 3 se representan las citadas velocidades. Se observa un descenso brusco de velocidad tras los 5-7 primeros ciclos de calentamiento/enfriamiento, valores que -dentro de las fluctuaciones propias del método- se mantienen constantes tras los posteriores ciclos.
The impact of heating and cooling on the velocity of the ultrasonic pulses penetrating the specimens is summarized in Figure 3. Velocity declined sharply after the first five or seven cycles and subsequently remained essentially constant, disregarding the minor fluctuations inherent in the technique.

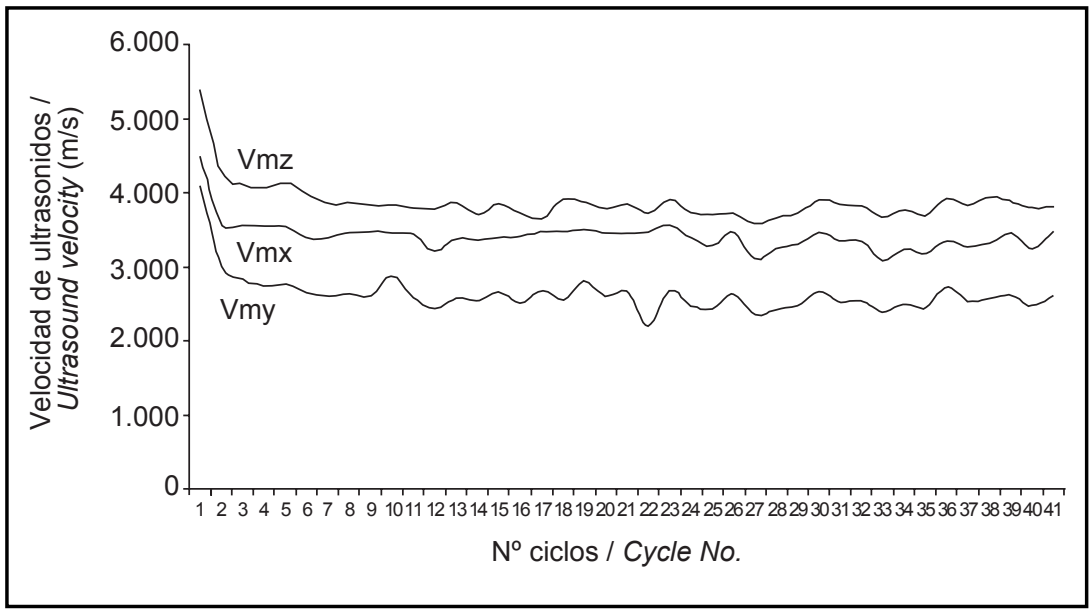

Figura 3. Velocidad de propagación de ultrasonidos (V) tras cada ciclo de $100 /-20{ }^{\circ} \mathrm{C}$, según las tres direcciones $(z, x$ e $y)$ de la probeta.

Figure 3. Ultrasound velocity (V) after each $100 /-20^{\circ} \mathrm{C}$ cycle along the three axes of the specimen.

En la Figura 4 se recogen análogos valores tras someter las probetas a ciclos entre $75^{\circ} \mathrm{C}$ y $-20^{\circ} \mathrm{C}$. Como en el caso anterior, las disminuciones de velocidad tienen lugar tras los 5-7 primeros ciclos, y posteriormente los valores permanecen constantes. Las variaciones porcentuales de velocidad son, en este caso, inferiores.

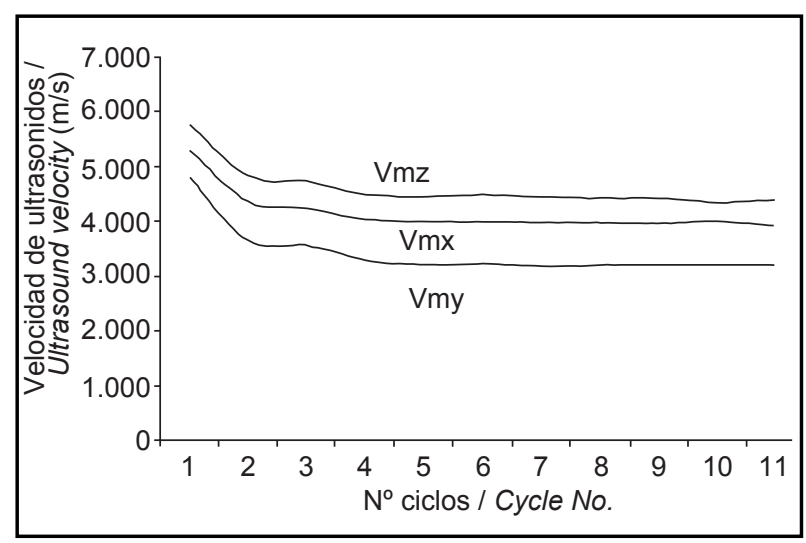

Figura 4. Velocidad de propagación de ultrasonidos $(\mathrm{V})$ tras cada ciclo de $75 /-20^{\circ} \mathrm{C}$, según las tres direcciones $(z, x$ e y) de la probeta.

Figure 4. Ultrasound velocity (V) after each $75 /-20^{\circ} \mathrm{C}$ cycle along the three axes of the specimen.
Figure 4 shows the values for specimens heated and cooled at temperatures ranging from 75 to $-20^{\circ} \mathrm{C}$. The pattern observed was similar: a decline in velocity followed by a flattening of the curve, although in this case the variations were smaller.

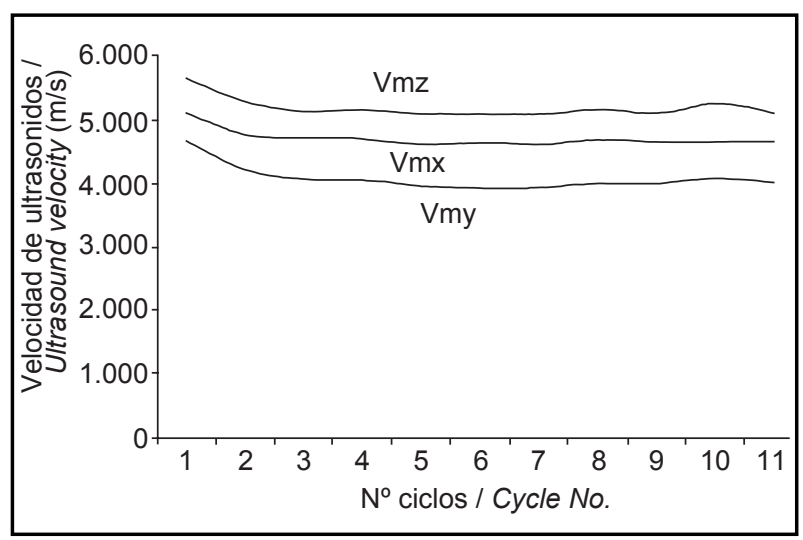

Figura 5. Velocidad de propagación de ultrasonidos $(\mathrm{V})$ tras cada ciclo de $50 /-20^{\circ} \mathrm{C}$, según las tres direcciones $(z, x$ e y) de la probeta.

Figure 5. Ultrasound velocity (V) after each $50 /-20^{\circ} \mathrm{C}$ cycle along the three axes of the specimen. 
En la Figura 5 se recogen en este caso los valores correspondientes a probetas sometidas a variaciones de temperatura entre $50^{\circ} \mathrm{C}$ y $-20^{\circ} \mathrm{C}$, observándose igualmente un descenso paulatino de velocidad de ultrasonidos hasta los 4 primeros ciclos. En este caso las disminuciones porcentuales son bastante inferiores a las debidas a los anteriores tratamientos.

En la Figura 6 se recogen los resultados correspondientes a someter las probetas a ciclos entre $-20^{\circ} \mathrm{C}$ y temperatura ambiente. Las disminuciones de velocidad son muy inferiores a las observadas en los anteriores casos (oscilan entre el $5 \%$ en la dirección $Z$ y el 9-10\% para la dirección Y).
The readings for specimens subjected to the narrowest range of fluctuations, 50 to $-20^{\circ} \mathrm{C}$, are shown in Figure 5 , where UPV is observed to have declined gradually during the first four cycles. The percentage decreases were considerably smaller in this than in the two preceding graphs.

Figure 6 shows the values for specimens cooled to $-20^{\circ} \mathrm{C}$ and then warmed to laboratory temperature. Here velocity declined much less than in the three preceding experiments, by just $5 \%$ in direction $Z$ and 9 to $10 \%$ in direction $Y$.

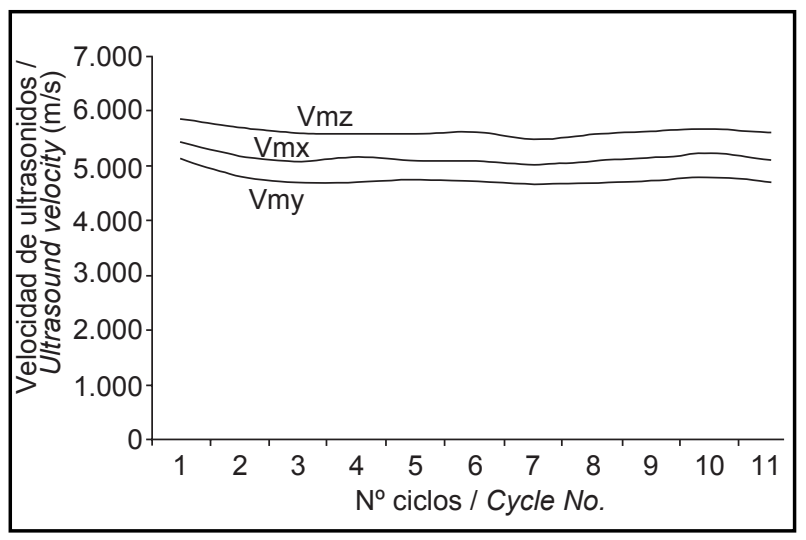

Figura 6. Velocidad de propagación de ultrasonidos $(\mathrm{V})$ tras cada ciclo de temp. ambiente/-20 으, según las tres direcciones $(z, x$ e $y)$ de la probeta.

Figure 6. Ultrasound velocity $(\mathrm{V})$ after each laboratory temperature $/-20^{\circ} \mathrm{C}$ cycle along the three axes of the specimen.

Finalmente, y por lo que se refiere a ultrasonidos, en la Tabla 1 se recogen los datos correspondientes al mes de enfriamiento de las probetas a $-20^{\circ} \mathrm{C}$. La variación de valores es irrelevante.
Lastly, the ultrasound readings for specimens stored at $-20^{\circ} \mathrm{C}$ for 30 days given in Table 1 show that the variations were not statistically significant.

Tabla 1 / Table 1

Valores medios de velocidad $(\mathrm{m} / \mathrm{s})$ de transmisión de ultrasonidos y sus variaciones tras mantener el material un mes a $-20{ }^{\circ} \mathrm{C}$, las medidas se efectuaron una vez alcanzada la temperatura ambiente según las tres direcciones $(z, x, y)$ de la probeta.

Mean ultrasound velocities $\left(\mathrm{m} / \mathrm{s}\right.$ ) in Macael marble and variations after storage for one month at $-20{ }^{\circ} \mathrm{C}$ (measurements taken along the three axes of the prismatic specimen after return to laboratory temperature).

\begin{tabular}{|c|c|c|c|c|c|c|}
\hline Ciclos / Cycle & $\mathbf{V m z}$ & $\mathbf{V m x}$ & $\mathbf{V m y}$ & $-\Delta \mathbf{V m z}(\%)$ & $-\Delta \mathbf{V m x}(\%)$ & $-\Delta \mathbf{V m y}(\%)$ \\
\hline 1 & 5546 & 5045 & 4694 & $0.00 \%$ & $0.00 \%$ & $0.00 \%$ \\
\hline 2 & 5526 & 5100 & 4728 & $0.36 \%$ & $1.09 \%$ & $0.72 \%$ \\
\hline 3 & 5580 & 5072 & 4609 & $0.61 \%$ & $0.54 \%$ & $-1.81 \%$ \\
\hline Std & 27 & 28 & 61 & & & \\
\hline
\end{tabular}

V: notación estándar para las ondas en métodos ultrasónicos / standard notation for waves in ultrasound techniques. $\Delta$ : incremento / increment.

Std.: Desviación estándar / Standard deviation.

En la Tabla 2 se recogen las disminuciones de velocidad $(\Delta \%)$ según las tres direcciones de la probeta y tras los distintos ciclos de calentamiento/enfriamiento. Se observa que, en todos los casos y a través de todos los
Table 2 summarizes the decline $(\Delta \%)$ in ultrasound velocity along the three axes after each cycling series. The velocity values were consistently highest in direction $Z$ and lowest along axis $Y: V z>V x>V y$. Moreover, thermal 
tratamientos, se mantiene $\mathrm{V} z>\mathrm{V} x>\mathrm{Vy}$. Asimismo, y con carácter general, la incidencia de los tratamientos sobre la velocidad de propagación de los ultrasonidos $(\% \Delta \mathrm{V})$ es de orden análogo en las direcciones $Z$ y X (paralelas a los bandeados grisáceos), y de mayor orden en la dirección $Y$ (perpendicular a dichos bandeados), resultados concordantes con los obtenidos en estudios precedentes (18) y (19). cycling affected UPV (\% $\%$ V) similarly in directions $Z$ and $X$ (parallel to the grey bands) but more significantly in direction $Y$ (perpendicular to the bands). These findings concur with the results of prior studies (18) and (19).

Tabla 2 / Table 2

Valores medios de velocidad $(\mathrm{m} / \mathrm{s})$ de transmisión de ultrasonidos y sus variaciones, de las series, tras cada ciclo de $100 /-20{ }^{\circ} \mathrm{C}$, $75 /-20{ }^{\circ} \mathrm{C}, 50 /-20{ }^{\circ} \mathrm{C}, 25 /-20^{\circ} \mathrm{C}$ y $-20^{\circ} \mathrm{C}$ (1 mes) según las tres direcciones $(\mathrm{z}, \mathrm{x}, \mathrm{y})$ de la probeta.

Mean ultrasound velocities $(\mathrm{m} / \mathrm{s})$ in Macael marble and variations after temperature cycling at $100 /-20{ }^{\circ} \mathrm{C}, 75 /-20^{\circ} \mathrm{C}, 50 /-20{ }^{\circ} \mathrm{C}$ $25 /-20{ }^{\circ} \mathrm{C}$ and $-20^{\circ} \mathrm{C}$ (1 month) (measurements taken along the three axes of prismatic specimens).

\begin{tabular}{|c|c|c|c|c|c|c|}
\hline Ciclos/Cycling range & $-\mathbf{\Delta V ( \% )}$ & Std & $\mathbf{X}$ & Std & $\mathbf{Y}$ & Std \\
\hline $100 /-20^{\circ} \mathrm{C}$ & 30 & \pm 5 & 28 & \pm 5 & 38 & \pm 7 \\
\hline $75 /-20^{\circ} \mathrm{C}$ & 24 & \pm & 26 & \pm & 33 & \pm \\
\hline $50 /-20^{\circ} \mathrm{C}$ & 10 & \pm & 9 & \pm & 15 & \pm \\
\hline $25 /-20^{\circ} \mathrm{C}$ & 5 & \pm & 6 & \pm & 8 & \pm \\
\hline$-20^{\circ} \mathrm{C}(1 \mathrm{mes}) / 1$ month & $<1$ & \pm & 1 & \pm & 2 & \pm \\
\hline
\end{tabular}

V: notación estándar para las ondas en métodos ultrasónicos / standard notation for waves in ultrasound techniques. $\Delta$ : incremento / increment.

Std.: Desviación estándar / Standard deviation.

Los valores de anisotropía total resultantes son bastante próximos a los propuestos por otros autores (21) y (22) para mármoles de este tipo mientras que la relativa resulta algo mayor en nuestro caso. Hay un aumento paulatino de la anisotropía total con el aumento de temperatura de los ciclos térmicos, mientras que la relativa no varía apreciablemente teniendo en cuenta las oscilaciones implícitas al método instrumental $( \pm 5 \%)$.
While total anisotropy was similar to the values reported by other authors (21) and (22) for this type of marble, the relative anisotropy detected here was somewhat higher. Total anisotropy increased gradually with rises in temperature, whereas relative anisotropy did not vary materially. The fluctuations in the latter were so minor as to be attributable to instrumental factors ( $\pm 5 \%)$.

Tabla 3 / Table 3

Valores medios de Índice de anisotropía ( $\Delta$ M: índice de anisotropía total en \%; $\Delta \mathrm{m}$ : índice de anisotropía relativa a la dirección de los bandeados grisáceos para los distintos tratamientos térmicos.

Mean anisotropy index values ( $\Delta \mathrm{M}$ : total anisotropy index in \%; $\Delta \mathrm{m}$ : relative anisotropy in the direction of the grey bands after temperature cycling.

\begin{tabular}{|c|c|c|c|c|}
\hline & Sin tratamiento / Control & $\mathbf{1 0 0 / - 2 0}$ & $\mathbf{7 5 / - 2 0}$ & $\mathbf{5 0 / - 2 0}$ \\
\hline$\Delta \mathrm{M}(\%)$ & 12.36 & 28.25 & 22.71 & 17.27 \\
\hline$\Delta \mathrm{m}(\%)$ & 10.38 & 8.91 & 11.09 & 9.21 \\
\hline
\end{tabular}

En la Tabla 4 se recogen los valores de: carga de rotura, módulo elástico y la deformación del material correspondiente dentro de su tramo elástico, que tras los distintos ciclos, se obtienen a partir de las pruebas de resistencia mecánica (registro de esfuerzo/deformación hasta rotura por compresión); se incluyen asimismo las diferencias de comportamiento respecto al material no tratado. Como en los anteriores ensayos, son importantes las disminuciones en las prestaciones mecánicas del material tras ser sometido a los ciclos de $100 /-20{ }^{\circ} \mathrm{C}$, menos acusadas tras los ciclos de 75/$20^{\circ} \mathrm{C}$, y poco representativos tras los ciclos de $50 /-20^{\circ} \mathrm{C}$.
The compression test findings on failure load, modulus of elasticity and strain within the elastic range of the stone are given in Table 4. The differences between the treated and control specimens are also shown. The pattern observed for the mechanical properties was similar to the findings for UPV: the decline was significant after $100 /-20^{\circ} \mathrm{C}$, less perceptible after 75/$20{ }^{\circ} \mathrm{C}$ and insignificant after 50/-20 ${ }^{\circ} \mathrm{C}$ cycling. 
Tabla 4 / Table 4

Valores medios y variación de carga de rotura, $(\mathrm{KN})$, módulo elástico $(\mathrm{Gpa})$, límite elástico $(\mathrm{Mpa})$ y deformación $(\mu \mathrm{m} / \mathrm{m})$ del material después de diferentes ciclos.

Mean failure load $(\mathrm{kN})$, modulus of elasticity $(\mathrm{GPa})$, yield stress $(\mathrm{MPa})$ and strain $(\mu \mathrm{m} / \mathrm{m})$ values for Macael marble and variations after temperature cycling.

\begin{tabular}{|c|c|c|c|c|c|c|c|c|}
\hline $\begin{array}{c}\text { Tratamiento / } \\
\text { Cycling range }\end{array}$ & $\begin{array}{c}\text { Carga de rotura / } \\
\text { Failure load } \\
\mathbf{( k N )}\end{array}$ & $-\Delta(\%)$ & $\begin{array}{c}\text { Módulo elástico / } \\
\text { Modulus of } \\
\text { elasticity (Gpa) }\end{array}$ & $-\Delta(\%)$ & $\begin{array}{c}\text { Comport. } \\
\text { elástico / } \\
\text { Yield stress } \\
\text { (tensión MPa) }\end{array}$ & $-\Delta(\%)$ & $\begin{array}{c}\text { Deformación / } \\
\text { Strain }(\mu \mathrm{m} / \mathbf{m})\end{array}$ & $\Delta(\%)$ \\
\hline $100 /-20^{\circ} \mathrm{C}$ & 183 & 16 & 46 & 38 & 56 & 19 & 1500 & 47 \\
\hline $75 /-20^{\circ} \mathrm{C}$ & 192 & 12 & 56 & 24 & 63 & 9 & 1250 & 23 \\
\hline $50 /-20^{\circ} \mathrm{C}$ & 208 & 5 & 68 & 8 & 65 & 6 & 1040 & 2 \\
\hline $\begin{array}{c}\text { Sin tratam. / } \\
\text { Control }\end{array}$ & 219 & - & 74 & - & 69 & - & 1017 & - \\
\hline
\end{tabular}

$\Delta$ : incremento / increment.

En la Tabla 5 se recogen los valores de dureza de Schmidt $(r)$, así como los de resistencia a compresión $\left(\sigma_{c}\right)$ y módulo de elasticidad $\left(\mathrm{E}_{\mathrm{t}}\right)$ según las tres direcciones de cada probeta tras someterlas a ciclos entre $100^{\circ} \mathrm{C} /-$ $20^{\circ} \mathrm{C}, 75^{\circ} \mathrm{C} /-20^{\circ} \mathrm{C}$ y $50^{\circ} \mathrm{C} /-20^{\circ} \mathrm{C}$ respectivamente; estos valores se han calculado considerando que la densidad del mármol blanco de Macael estudiado es de 2,75 $\mathrm{gr} / \mathrm{cm}^{3}$ (18). Se recogen asimismo las diferencias porcentuales de dichos valores respecto a material no tratado. Se observan variaciones acusadas tras los ciclos de $100{ }^{\circ} \mathrm{C}$, y bastante más moderadas tras los ciclos de $75^{\circ} \mathrm{C}$; las variaciones tras los ciclos de $50^{\circ} \mathrm{C}$ están dentro de las oscilaciones implícitas al método instrumental $( \pm 5 \%)$. En estos ensayos las implicaciones direccionales no son perceptibles.
Table 5 gives Schmidt hardness ( $r$ ), compressive strength $\left(\sigma_{c}\right)$ and modulus of elasticity $\left(E_{t}\right)$ along the three axes of thermally cycled specimens. These values were calculated assuming marble density to be 2.75 $\mathrm{g} / \mathrm{cm}^{3}$ (18). The percentage differences between these values and the values for the control specimens are also shown. The variations were found to be significant after $100^{\circ} \mathrm{C}$ cycling, much more moderate after $75^{\circ} \mathrm{C}$ cycling and attributable to instrumental fluctuations after $50^{\circ} \mathrm{C}$ cycling. No material direction-dependent variations were detected in these results.

Tabla 5 / Table 5

Valores medios y variación de dureza superficial o Esclerómetro de Schmidt $(r)$, resistencia a compresión $\left(\sigma_{c}\right)$ y módulo de elasticidad $\left(\mathrm{E}_{\mathrm{t}}\right)$ de muestras después de diferentes ciclos, según las tres direcciones $(\mathrm{z}, \mathrm{x}, \mathrm{y})$ de la probeta.

Mean Schmidt surface hardness $(r)$, compressive strength $\left(\sigma_{c}\right)$ and modulus of elasticity $\left(E_{t}\right)$ values measured along the three axes of specimens after temperature cycling.

\begin{tabular}{|c|c|c|c|c|c|}
\hline Dirección / Direction & & Sin tratamiento / Control & $100 /-20^{\circ} \mathrm{C}$ & $75 /-20^{\circ} \mathrm{C}$ & $50 /-20^{\circ} \mathrm{C}$ \\
\hline \multirow[t]{6}{*}{$\bar{Z}$} & $\mathrm{r}$ & 35.5 & 25.0 & 32.5 & 34.0 \\
\hline & $-\Delta r(\%)$ & - & 28.6 & 8.5 & 4.2 \\
\hline & $\sigma_{c}(\mathrm{MPa})$ & 70.0 & 40.0 & 60.0 & 68.5 \\
\hline & $-\Delta \sigma_{c}(\%)$ & - & 42.8 & 14.3 & 2.1 \\
\hline & $\mathrm{E}_{\mathrm{t}}\left(\mathrm{psi} .10^{6}\right)$ & 6.0 & 3.9 & 5.5 & 5.8 \\
\hline & $-\Delta \mathrm{E}_{\mathrm{t}}(\%)$ & - & 35.0 & 8.3 & 3.3 \\
\hline \multirow[t]{6}{*}{$x$} & $r$ & 33.5 & 22.0 & 31.2 & 32.5 \\
\hline & $-\Delta r(\%)$ & - & 34.3 & 6.9 & 3.0 \\
\hline & $\sigma_{c}(\mathrm{MPa})$ & 65.0 & 36.0 & 55.0 & 60.0 \\
\hline & $-\Delta \sigma_{c}(\%)$ & - & 44.6 & 15.4 & 7.7 \\
\hline & $\mathrm{E}_{\mathrm{t}}\left(\mathrm{psi} .10^{6}\right)$ & 5.8 & 3.3 & 5.0 & 5.5 \\
\hline & $-\Delta \mathrm{E}_{\mathrm{t}}(\%)$ & - & 43.0 & 13.7 & 5.2 \\
\hline \multirow[t]{6}{*}{$Y$} & $r$ & 36.0 & 26.0 & 32.0 & 33.5 \\
\hline & $-\Delta r(\%)$ & - & 27.8 & 11 & 6.9 \\
\hline & $\sigma_{c}(\mathrm{MPa})$ & 72.0 & 42.0 & 60.0 & 68.0 \\
\hline & $-\Delta \sigma_{c}(\%)$ & - & 41.7 & 16.7 & 5.5 \\
\hline & $\mathrm{E}_{\mathrm{t}}\left(\mathrm{psi} .10^{6}\right)$ & 6.1 & 4.1 & 5.4 & 5.8 \\
\hline & $-\Delta \mathrm{E}_{\mathrm{t}}(\%)$ & - & 32.8 & 11.5 & 4.9 \\
\hline
\end{tabular}

$\Delta$ : incremento / increment. 
En la Figura 7 se reúnen imágenes de microscopía electrónica de muestras sometidas a los distintos ciclos. En las muestras sometidas a ciclos de $100 /-20^{\circ} \mathrm{C}$ donde se observan ocasionalmente zonas superficiales de espesor mínimo muy degradas. En las muestras sometidas a 75/$20^{\circ} \mathrm{C}$ este efecto es mucho menos perceptible, y nada perceptible en las sometidas a $50 /-20^{\circ} \mathrm{C}$.
SEM images of the specimens subjected to heating/cooling are shown in Figure 7. While the 100/-20 ${ }^{\circ} \mathrm{C}$ samples sporadically exhibited intense superficial decay, this was much less visible in the $75 /-20{ }^{\circ} \mathrm{C}$ specimens and imperceptible in the $50 /-20^{\circ} \mathrm{C}$ specimens.

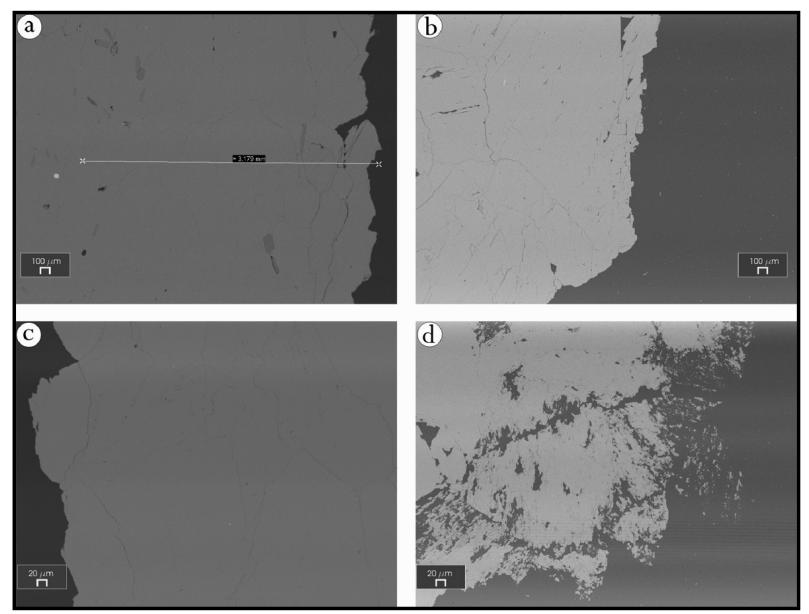

Figura 7. Imagen de microscopía electrónica (SEM) de muestras sometidas a distintos ciclos (a), 50/-20 ${ }^{\circ} \mathrm{C}$ ciclos (b), $75 /-20{ }^{\circ} \mathrm{C}$ ciclos (c) y $100 /-20^{\circ} \mathrm{C}$ ciclos (d). Nótese lo degradado de la zona superficial de la muestra d.

Figure 7. SEM micrograph of specimens after cycling at (a) 50/-20 ${ }^{\circ} \mathrm{C}$; (b) $75 /-20{ }^{\circ} \mathrm{C}$; (c) $100 /-20{ }^{\circ} \mathrm{C}$; and (d) $100 /-20{ }^{\circ} \mathrm{C}$. *Note the decay in the area closest to the surface in specimen $d$.

\section{CONCLUSIONES}

Los resultados aportados indican la alta sensibilidad del mármol blanco Macael a oscilaciones térmicas no excesivamente elevadas como es el caso de los ciclos entre $75 /-20^{\circ} \mathrm{C}$ y $100 /-20^{\circ} \mathrm{C}$; son evidentes las disminuciones de las velocidades de propagación de ultrasonidos así como de los parámetros mecánicos tras someter el material a ciclos de 100 y $75^{\circ} \mathrm{C}$. Respecto a los ciclos de $50 /-20{ }^{\circ} \mathrm{C}$, aunque las variaciones en los distintos parámetros suelen estar dentro de los márgenes de variabilidad de las distintas técnicas empleadas, el hecho de que en todos los casos estas variaciones sean en términos de disminución, nos permite considerar la temperatura de $50{ }^{\circ} \mathrm{C}$ como el umbral térmico a partir del cual el material comienza a verse afectado por estas elevaciones periódicas de temperatura. Por otra parte, y como las variaciones en la velocidad de propagación de los ultrasonidos ponen de manifiesto, la incidencia de las oscilaciones térmicas es relativamente rápida, teniendo lugar tras los 5-7 primeros ciclos; estas mismas velocidades parecen indicar que posteriormente las características del material no varían sensiblemente. Parece producirse, por tanto, un reajuste o adecuación del comportamiento del material a esta situación, de manera que posteriores ciclos no producen variaciones apreciables, sobre todo teniendo en cuenta la variabilidad de las propias técnicas

\section{CONCLUSIONS}

The findings show that white Macael marble is highly sensitive to medium-range temperature fluctuations such as 75/-20 and 100/-20 \% C. Ultrasound velocity and mechanical properties clearly declined in stone exposed to these conditions. The variations recorded for specimens subjected to the narrowest temperature range, 50/-20 ${ }^{\circ} \mathrm{C}$, could normally be attributed to instrumental fluctuations. Nonetheless, the fact that the values represented a consistent decline in the characteristics that contribute to durability may well be an indication that $50^{\circ} \mathrm{C}$ is a threshold value above which this stone is affected by periodic rises in temperature. The decline in ultrasound velocity showed that thermal fluctuation affected the stone in the very short term, i.e., in the first 5-7 cycles, with no subsequent alterations. The marble would, then, appear to adjust to environmental conditions early on, with no perceptible changes taking place afterward that could not be 
(variaciones de velocidad de propagación de ultrasonidos y medidas de dureza de Schmidt). Sería necesaria la acción continuada de estas variaciones térmicas a lo largo de dilatados periodos de tiempo para poner de manifiesto un posterior incremento en el efecto de los mismos.

Los resultados recogidos en las Tablas 1 y 2 y Figura 5 ponen de manifiesto que son fundamentalmente las etapas de calentamiento las que afectan a los valores de velocidad de ultrasonidos, mientras que las etapas de enfriamiento por debajo de la temperatura ambiente apenas si afectan.

Es evidente la correlación presente entre los valores de velocidad de propagación de ultrasonidos, los proporcionados por los ensayos de rotura por compresión y los obtenidos a partir de las medidas de dureza de Schmidt. Así, en todos los casos, todos los parámetros citados disminuyen según se incrementa el gradiente térmico a que se somete el material, lo que permite considerar los valores de velocidad de ultrasonidos y de dureza de Schmidt (ensayos ambos no destructivos) como adecuados para evaluar la incidencia de las fluctuaciones térmicas a las que un material pétreo está expuesto, sobre sus prestaciones o capacidad mecánica.

Estudios precedentes ya citados (18) (19) (21) y (22), así como los datos aquí expuestos, indican la notable anisotropía del mármol blanco Macael, anisotropía que sería atribuible tanto a la presencia de los bandeados grisáceos como a una posible orientación preferencial de los cristales de calcita. En un trabajo anterior sobre este mismo tipo de mármol (18) se ponía de manifiesto que, aunque no era perceptible en lámina delgada una orientación preferencial de los granos cristalinos, determinaciones mediante platina teodolítica y de intensidades relativas de DRX indicaban una cierta -más bien escasa - tendencia del eje c de los cristales a concentrarse según direcciones a $45^{\circ}$ de la dirección $Z$ (longitudinal) de las probetas. Los resultados aquí expuestos indican un aumento de la anisotropía total del material conforme aumenta la temperatura de los ciclos, mientras que la relativa respecto a las direcciones paralelas a los bandeados grisáceos se mantiene, lo que nos permite resaltar la incidencia de dichos bandeados en el comportamiento del material, de manera que, a pesar de lo escaso de su presencia en el material empleado en este trabajo, los valores de los distintos parámetros medidos siempre presentan una variación porcentual mayor en la dirección perpendicular a los mismos.

En trabajo anterior sobre este mismo tipo de material (19) se indicaba que tras 200 ciclos de $100 /-20^{\circ} \mathrm{C}$ en las imágenes de SEM eran claramente perceptibles fenómenos de desagregación o fisuración en superficie, aunque no iban acompañadas de afecciones superficiales visibles a escala attributed to the variability of the ultrasound and Schmidt hardness techniques used. Longer test periods would be needed to determine the long-term impact of temperature fluctuations.

According to the data shown in Tables 1 and 2 and Figure 5, the UPV values were primarily affected by the heat, whereas low temperatures had barely any impact at all.

The ultrasound velocity, compression failure and Schmidt hardness values were clearly correlated. The values of all these parameters consistently declined as the thermal gradient rose. The inference is that ultrasound velocity and Schmidt hardness can validly assess the effects of temperature fluctuation and, as non-destructive methods, are to be preferred over testing for mechanical properties.

The prior studies cited earlier (18, 19, 21 and 22), in conjunction with the present findings, proved that white Macael marble is essentially anisotropic. This may be due to its grey bands or a possible prevalence in the orientation of its calcite crystals. One of the above studies (18), using XRD and theodolite techniques, showed that such prevalence could not be identified in the examination of thin sections, although the crystals did exhibit a vague tendency to align their c-axes at a $45^{\circ}$ angle to the $Z$ (longitudinal) axis of the specimens. According to the present findings, total anisotropy increased in the marble with rising temperatures, while the relative anisotropy along the directions parallel to the grey bands remained unchanged. This is an indication of the important role of these bands in marble behaviour, for despite their scarcity in the material used, the values of the parameters studied consistently exhibited greater percentage variation in the direction parallel to the bands.

In another prior paper (19), surface flaking and fissuring were shown to be clearly visible in SEM images after 200 full $100 /-20^{\circ} \mathrm{C}$ cycles, while macroscopically they remained imperceptible. Similarly, in the present study, the optical and SEM micrographs revealed that the 
macroscópica. En el presente estudio tanto las imágenes de microscopía óptica como las de SEM también manifiestan una cierta afección a escala granular de la zona superficial de las muestras que han estado sometidas a ciclos de $100 /-20^{\circ} \mathrm{C}$ (Figuras. 2 y 6 ), aunque tampoco son observables a escala macroscópica (visualmente) alteraciones superficiales de estas muestras. A este respecto resaltar que además de la amplitud del gradiente u oscilación térmica, la acción continuada durante décadas o siglos de los ciclos de calentamiento/enfriamiento tiene una importancia considerable en la consideración de los efectos de fatiga mecánica que pudiera llevar asociada la insolación (34) y (35). Por otra parte, además de los cambios diarios, también influirán los de corto rango (fluctuaciones de temperatura por viento, nubes, a lo largo del día), así como otros aspectos (variaciones combinadas temp/HR, etc.), todo ello además a lo largo de dilatados periodos de tiempo, que producirán una manifestación macroscópica de la afección de estos ciclos de "bajamedia" temperatura. Por tanto, deterioros macroscópicos en forma de desplacados, pitting, u otras de índole superficial en este tipo de material, y por este tipo de gradientes térmicos no serían visibles sino tras un gran número de ciclos (quizás varios años), lo que parece fuera de las posibilidades de este tipo de ensayos.

\section{AGRADECIMIENTOS}

La investigación presentada en este artículo es parte del Proyecto MAT 2004-06804-CO2-0 del Plan Nacional de Investigación científica, Desarrollo e Innovación Tecnológica (Ministerio de Ciencia y Tecnología) y llevado a cabo en el Grupo de Investigación RNM 0179 de la Junta de Andalucía. Los datos de SEM han sido obtenidos del Centro de Instrumentación Científica (CIC) de la Universidad de Granada. surface grains were impacted in specimens subjected to 100/-20 ${ }^{\circ} \mathrm{C}$ cycling (Figures 2 and 6), although such alterations were not visible to the naked eye. In addition to the range of the thermal gradient, however, continuous heating and cooling over decades or centuries has a considerable impact on the mechanical fatigue associated with insolation (34 and 35). In addition to daily fluctuations, short-term temperature variations due to wind or clouds and other longer term factors (combined effects of temperature and relative humidity, for instance) also exert influence that may lead to macroscopic alterations induced by these narrow to medium range temperature cycles. Visible decay such as scaling, pitting or other surface defects in this type of marble when exposed to thermal gradients such as tested here would only appear after much longer periods (possibly years) than generally addressed in this type of study.

\section{ACKNOWLEDGEMENTS}

The research discussed here forms part of Project MAT 2004-06804-CO2-0, funded by the National Plan for Scientific Research, Development and Technological Innovation (Ministry of Science and Technology), and conducted by Regional Government of Andalusia Research Group 0179. The SEM data were supplied by the University of Granada's Scientific Instruments Centre.

\section{BIBLIOGRAFÍA / BIBLIOGRAPHY}

(1) Griggs, D. T.: "The factor of fatigue in rock exfoliation". Journal of Geology, no 44 (1936), pp. 783-796.

(2) Gómez-Heras, M.; Smith, B. J. and Fort, R.: "Surface temperature differences between minerals in crystalline rocks: Implications for granular disaggregation of granites through thermal". Geomorphology 78 (1991), pp. 236-249. i:10.1016/j.geomorph.2005.12.013

(3) Goudie, A. S. and Viles, H. A.: "The thermal degradation of marble". Acta Universitatis Carolinae, Geographica, 35 (2000), pp. 7-16.

(4) Hall, K. and Andre, M. F.: "Rock thermal data at the grain scale: applicability to granular desintegration in cold environments". Earth Surface Processes and Landforms, 28 (2003), pp. 823-836. doi:10.1002/esp.494

(5) Koch, A. and Siegesmund, S.: "The combined effect of moisture and temperature on the anomalous expansion behaviour of marble". Environmental geology, 46 (2004), pp. 350-363. doi:10.1007/s00254-004-1037-9

(6) Malaga-Starzec, K.; Lindquist, J. E. \& Schouenborg, B.: "Experimental study on the variation in porosity of marble as a function of temperature. Natural Stone, Weathering Phenomena, Conservation Strategies and Case Studies, Geol". Soc. Special Pub., 205, London (2002).

(7) Siegesmund, S.; Ullemeyer, K.; Weiss, T. and Tschegg, E. K.: "Physical weathering of marbles caused by anisotropic thermal expansion". International Journal of Earth Sciences, 89 (2000a.), pp. 170-182. doi:10.1007/s005310050324

(8) Siegesmund, S.; Weiss, T. and Tschegg, E. K.: "Control of marble weathering by thermal expansion and rock fabrics". In: V. Fassina (ed.), Proceedings of the 9th International Congress on Deterioration and Conservation of Stone, Venice, June 19-24, 2000. Elsevier, Ámsterdam (2000b), pp. 205-213. 
(9) Turkington, A. V.; Smith, B. J. and Basheer, P. A. M.: "Sb-surface temperature and moisture changes in sandstone". In: R. Prikryl y H. A. Viles (eds.), Understanding and Managing of Stone Decay. Charles University in Prague, The Karolinum Press, Prague (2002), pp. 113-126.

(10) Warke, P. A. and Smith, B. J.: "Effects of direct and indirect heating on the validity of rock weathering simulation studies and durability tests". Geomorphology, 22 (3-4) (1998), pp. 347-357. doi:10.1016/S0169-555X(97)00078-0

(11) Weiss, T.; Fuller (Jr), E. R. and Siegesmund, S.: "Thermal stresses in calcite and dolomite marbles quantified by finite element modelling". In: S. Siegesmund, T. Weiss y A. Vollbrecht (eds.), Natural stone, weatherin phenomena, conservation strategies, and case studies. Geological Society special publication, vol. 205. Geological Society, London (2002), pp. 84-94.

(12) Weiss, T.; Siegesmund, S. and Fuller (Jr), E. R.: "Thermal degradation of marble: indications from finite-element modelling". Building and Environment, 38(9-10) (2003), pp. 1251-1260. doi:10.1016/S0360-1323(03)00082-9

(13) Weiss, T.; Siegesmund, S.; Kirchner, D. and Sippel, J.: "Insolation weathering and hygric dilatation: two competitive factors in stone degradation". Environmental Geology, 46 (2004), pp. 402-413. doi:10.1007/s00254-004-1041-0

(14) Galán, E.; Guerrero, M. A.; Vázquez, M. A. \& Zezza, F.: "Progressive deterioration of marble columns by thermal changes in relation to their state of superficial decay". 7th. International Congress on Deterioration and Conservation of Stone. Lisboa, vol. 1 (1992), pp. 905-913.

(15) Yang, W. H.; Srolovitz, D. J.; Hassold, G. N. and Anderson, M. P.: "Microstructural Effects in the Fracture of Brittle Materials". In M. P. Anderson and A. D. Rollett (eds.), Simulation and Theory of Evolving Microstructures. The Metallurgical Society, Warrendale, Pennsylvania (1990), pp. 277-284.

(16) Yavuz, H.; Altindag, R.; Sarac, S.; Ugur, I. and Sengun, N.: "Estimating the index properties of deteriorated carbonate rocks due to freeze-thaw and thermal shock weathering". International Journal Rock Mechanics \& Mineral Science, 43 (2006), pp. 767-775.

(17) Sáez Pérez, M. P. y Rodríguez Gordillo, J.: "Estudio constructivo-estructural de la galería y columnata del Patio de los Leones de la Alhambra de Granada". Monográfica Biblioteca de Arquitectura y Restauración, no 9, Ed. Editorial Universidad de Granada. ISBN: 84338-3206-9 (2004), 136 pp.

(18) Sáez Pérez, P.: "Estudio de elementos arquitectónicos y composición de materiales del Patio de los Leones. Interacciones en sus causas de deterioro". Ed. Servicio de Publicaciones de la Universidad de Granada (2004), 429 pp.

(19) Rodríguez-Gordillo, J. y Sáez-Pérez, M. P.: "Effects of thermal changes on Macael marble: Experimental study". Construction and Building Materials, 20 (2006). pp. 355-365. doi:10.1016/j.conbuildmat.2005.01.061

(20) Bello, M. A.: Martín, L.; Martín, A.: "Scanning electron-microscopy to establish the marble weathering mechanism in the Alhambra of Granada (Spain)". Scanning Microscopy, 5 (1991), pp. 645-652.

(21) Zezza, U. and Sebastián Pardo, E.: "El mármol de Macael (Almería) en los monumentos históricos de Granada (España)". I Congreso Internacional Rehabilitación del patrimonio Arquitectónico y Edificación. Islas Canarias, vol. I, (1992), pp. 153-160.

(22) Sebastián Pardo, E.; Rodríguez Navarro, A.; Cultrone, G.; Urosevie, M. and Rodríguez Navarro, C.: "Caracterización de la anisotropía textural de mármoles comerciales". Macla, vol. 6 (2006), pp. 453-456.

(23) Bello, M. A.; Martín, L.; Martín, A.: "Decay and Treatment of Macael White Marble". Studies in Conservation, vol. 37 (3) (1992), pp. 193-200. doi:10.2307/1506346

(24) IGME. Mapa Geológico 1:50.000, MAGNA, Hoja no 103 (Macael) (1975).

(25) Gómez-Heras, M.: "Procesos y Formas de Deterioro térmico en Piedra Natural del Patrimonio Arquitectónico". Departamento de Petrología y Geoquímica, Univ. Complutense de Madrid. Tesis Doctoral (2005), 339 pp.

(26) Peel, R. F.: "Insolation weathering: Some mea surements of diurnal temperature changes in exposed rocks in the Tibesti region, central Sahara". Zeitschrift für Geomorphologie N.F. Suppl. Bd., 21 (1974), pp. 19-28.

(27) Kerr, A.; Smith, B. J.; Whalley, W. B. and McGreevy, J. P.: "Rock temperatures from southeast Morocco and their significance for experimental rock-weathering studies". Geology, 12 (1984). pp. 306-309. doi:10.1130/0091-7613(1984)12<306:RTFSMA>2.0.CO;2

(28) UNE 83-308.-86. Ensayos de hormigón. Determinación de la velocidad de propagación de los impulsos ultrasónicos; 1986.12 pp.

(29) NORMAL 22/86. CNR-ICR. Misura della Velocitá di Propagazione del Suono. Roma (1986), 7 pp.

(30) Guyader, J. and. Denis, A.: "Propagation des ondes les roches anisotropes sous contrainte évaluation de la qualité des schiste ardoisiers". Bulletin of Engineering Geology, 33 (1986), pp. 49-55.

(31) Zezza, U.: "Physical-mechanical properties of quarry and building stones". Advanced Workshop. Analytical Methodologies for the Investigation of Demaged Stone. Pavia (1990), $21 \mathrm{pp}$.

(32) UNE 22-187-85. Mármoles y calizas ornamentales. Ensayo de módulo elástico; (1985), 2 pp.

(33) Rock Classification Hammer. Instruction Manual. Control S.r.L. www.controls.it.

(34) Halsey, D. P.; Mitchel, D. J. and Dews, S. J.: "Influence of climatically induced cycles in physical weathering". Quarterly Journal of Engineering Geology, 31 (1998), pp. 359-367. doi:10.1144/GSL.QJEG.1998.031.P4.09

(35) Hall, K. and André, M. F.: "New insights into rock weathering from high-frequency rock temperature data: an Antarctic study of weathering by thermal stress". Geomorphology, 41 (1) (2001), pp. 23-35. doi:10.1016/S0169-555X(01)00101-5 